\title{
Broad Thorny Ganglion Cells: A Candidate for Visual Pursuit Error Signaling in the Primate Retina
}

\author{
Christian Puller, ${ }^{1}$ Michael B. Manookin, ${ }^{1}$ Jay Neitz, ${ }^{1}$ Fred Rieke, ${ }^{2,3}$ and $\oplus^{\oplus}$ Maureen Neitz ${ }^{1}$ \\ ${ }^{1}$ Department of Ophthalmology, ${ }^{2}$ Physiology and Biophysics Department, and ${ }^{3}$ Howard Hughes Medical Institute, University of Washington, Seattle, \\ Washington 98109
}

\begin{abstract}
Functional analyses exist only for a few of the morphologically described primate ganglion cell types, and their correlates in other mammalian species remain elusive. Here, we recorded light responses of broad thorny cells in the whole-mounted macaque retina. They showed ON-OFF-center light responses that were strongly suppressed by stimulation of the receptive field surround. Spike responses were delayed compared with parasol ganglion cells and other $\mathrm{ON}-\mathrm{OFF}$ cells, including recursive bistratified ganglion cells and A1 amacrine cells. The receptive field structure was shaped by direct excitatory synaptic input and strong presynaptic and postsynaptic inhibition in both $\mathrm{ON}$ and OFF pathways. The cells responded strongly to dark or bright stimuli moving either in or out of the receptive field, independent of the direction of motion. However, they did not show a maintained spike response either to a uniform background or to a drifting plaid pattern. These properties could be ideally suited for guiding movements involved in visual pursuit. The functional characteristics reported here permit the first direct cross-species comparison of putative homologous ganglion cell types. Based on morphological similarities, broad thorny ganglion cells have been proposed to be homologs of rabbit local edge detector ganglion cells, but we now show that the two cells have quite distinct physiological properties. Thus, our data argue against broad thorny cells as the homologs of local edge detector cells.
\end{abstract}

Key words: eye movements; ganglion cells; light responses; nonimage-forming vision; primate retina

\section{Introduction}

Retinal ganglion cells integrate the signals from presynaptic neurons and send this information in the form of action potentials (spikes) to higher visual centers of the brain, creating distinct functional channels that organize higher-level visual processing (Wässle, 2004). A comprehensive understanding of retinal ganglion cells and their role in vision is made difficult by several issues. These include the abundance and morphological heterogeneity of ganglion cell types, the different species used for investigation, the application of differing research techniques, and differences in nomenclature and cataloging principles. More than 10 different types of ganglion cells have been described in various mammalian species, and these cells can differ in mor-

Received Oct. 21, 2014; revised Feb. 18, 2015; accepted Feb. 28, 2015.

Author contributions: C.P., M.B.M., J.N., F.R., and M.N. designed research; C.P. and M.B.M. performed research; C.P., M.B.M., and F.R. analyzed data; C.P., M.B.M., J.N., F.R., and M.N. wrote the paper.

This work was supported by the German Research Foundation (DFG PU 469/2-1 to C.P.), the Helen Hay Whitney Foundation (to M.B.M.), the Howard Hughes Medical Institute (to F.R.), the National Institutes of Health (R01 EY09303, F32 EY024507, P30 EY01730, R01 EY11850), and Research to Prevent Blindness. We thank Ben Sivyer for valuable discussions and to Brian Schmidt for critical comments on an earlier version of the manuscript. We thank Paul Newman, Mark Cafaro, Shellee Cunnington, and Jing Huang for excellent technical assistance, as well as Juan Angueyra, Raunak Sinha, and the Tissue Distribution Program of the Washington National Primate Research Center (supported through National Institutes of Health Grant P51 0D010425) for providing primate tissue.

The authors declare no competing financial interests.

Correspondence should be addressed to either of the following: Christian Puller, Department of Neuroscience, Carl von Ossietzky University, Carl-von-0ssietzky-Str. 9-11, 26129 Oldenburg, Germany. E-mail: christian.puller@uni-oldenburg.de; or Maureen Neitz, Department of Ophthalmology, University of Washington, 750 Republican St., Seattle, WA 98109. E-mail: mneitz@uw.edu.

DOI:10.1523/JNEUROSCI.4369-14.2015

Copyright $\odot 2015$ the authors $\quad 0270-6474 / 15 / 355397-12 \$ 15.00 / 0$ phology, functional properties, and central projections (Berson, 2008; Masland, 2012). In primate, however, thorough studies of the ganglion cells' light-response properties are restricted to a small subset of types. Moreover, the available data cannot be conclusively brought into correspondence with results from ganglion cells of nonprimate species and vice versa. Such correspondence is needed, for example, to combine the wealth of behavioral data in primate with the genetic access in mouse to understand ganglion cell function.

A familiar example of possibly homologous cell types is the primate "broad thorny" ganglion cell, which shows a similar dendritic structure and stratification level in the inner plexiform layer (IPL) as the "local edge detector" (LED) ganglion cell in rabbit (Berson, 2008). Although the terminology varies across anatomical studies of this primate ganglion cell, we refer to it here as broad thorny ganglion cell [human: "thorny diffuse" (Peterson and Dacey, 2000); macaque: "T-group" or "maze" (Rodieck and Watanabe, 1993), "broad thorny" (Dacey et al., 2003), "S3 narrow thorny" (Yamada et al., 2005); marmoset: "hedge" (Ghosh et al., 1996), "broad thorny" (Szmajda et al., 2008; Ivanova et al., 2010; Percival et al., 2011, 2013; Moritoh et al., 2013)].

While the physiological properties of broad thorny cells are unknown, light responses of LED ganglion cells in rabbit are well investigated. They exhibit spike bursts at light onset and offset (ON-OFF center cells). The cells are named from the robust spike response elicited when a high-contrast edge is moved into or out of the receptive field center (Levick, 1967). Further key features include delayed light responses, a characteristic receptive field 
structure with strong surround suppression and fast postsynaptic inhibition (Devries and Baylor, 1997; Zeck et al., 2005; Roska et al., 2006; van Wyk et al., 2006; Russell and Werblin, 2010; Venkataramani et al., 2014).

Here, extracellular loose-patch and whole-cell voltage-clamp recordings were performed in the in vitro whole-mount preparation of macaque retina to provide the first functional analysis of response properties of broad thorny ganglion cells in the primate retina. The motivation of the work reported here is to expand the number of physiologically characterized primate ganglion cell types. A series of experiments were performed to test hypotheses about the role of these cells in vision, to probe synaptic mechanisms underlying their response properties, and to evaluate, based on functional evidence, whether or not broad thorny cells represent actual homologs of rabbit LED ganglion cells.

\section{Materials and Methods}

Tissue preparation and recordings. Eyes were dissected from deeply anesthetized macaque monkeys of either sex (Macacca fascicularis, M. nemestrina, and M. mulatta), obtained through the Tissue Distribution Program of the National Primate Research Center at the University of Washington. All procedures were approved by the University of Washington Institutional Animal Care and Use Committee.

The anterior segment of the eye, including vitreous body, was removed and the posterior segment, including retina, was stored for $\geq 1 \mathrm{~h}$ in a light-tight container in warm $\left(\sim 32^{\circ} \mathrm{C}\right)$ Ames solution (Sigma-Aldrich) equilibrated with $5 \% \mathrm{CO}_{2}$ and $95 \% \mathrm{O}_{2}$. Small pieces of retina $(2-4 \mathrm{~mm}$ on the side) were then dissected away from the supporting layers under infrared light to keep the retina dark adapted. Retinal pieces were wholemounted photoreceptor-side down onto a polylysine-coated glass slip and transferred to the recording chamber, where the tissue was continuously superfused with warm bicarbonate-buffered Ames solution flowing at $6-8 \mathrm{ml} / \mathrm{min}$.

We recorded from a total of 27 broad thorny ganglion cells, in addition to parasol and recursive bistratified ganglion cells and A1 amacrine cells in the ganglion cell layer of peripheral retina (eccentricity typically $>22^{\circ}$ ). Light-evoked spikes were recorded either in cell-attached mode using glass pipettes filled with Ames solution, or in whole-cell currentclamp mode with an intracellular solution containing (in $\mathrm{mm}$ ) the following: $125 \mathrm{~K}$-aspartate, $1 \mathrm{MgCl}_{2}, 10 \mathrm{KCl}, 10 \mathrm{HEPES}, 2$ EGTA, $1 \mathrm{CaCl}_{2}, 4$ Mg-ATP, and 0.5 Tris-GTP, pH $\sim 7.2$ with $\mathrm{K}-\mathrm{OH}, \sim 280 \mathrm{mOsm}$. To characterize light-evoked excitatory and inhibitory ganglion cell synaptic input, whole-cell voltage-clamp recordings were performed using pipettes filled with an internal solution containing (in $\mathrm{mM}$ ) the following: $105 \mathrm{CsCH}_{3} \mathrm{SO}_{3}, 10$ TEA-Cl, 20 HEPES, 10 EGTA, 2 QX-314, 5 Mg-ATP, and 0.5 Tris-GTP, $\mathrm{pH} \sim 7.3$ with $\mathrm{CsOH}, \sim 280 \mathrm{mOsm}$. Series resistance for voltage-clamp recordings was compensated by $50 \%$ at the time of recording and the remaining $50 \%$ off-line. The membrane potential was corrected off-line for the $\sim 10 \mathrm{mV}$ liquid junction potential between the recording solution and the extracellular medium. The pipette solution usually contained $0.1 \%$ Lucifer yellow $\mathrm{CH}$ (Sigma-Aldrich) or, in some instances, $1 \%$ neurobiotin (Vector Laboratories) for later recovery of cellular morphology.

Visual stimulation and data analysis. Stimuli from an organic lightemitting diode monitor (eMagin) were focused on the photoreceptors through a condenser lens. The monitor illuminated a circular area $(\sim 1$ $\mathrm{mm}$ in diameter) centered on the recorded cell's soma (vertical refresh, $60 \mathrm{~Hz}$ ). Spots and plaid patterns were modulated at a certain intensity $(I)$ around a mean level $(M)$, where percentage Michelson contrast was defined as $\left(I_{\max }-I_{\min }\right) /\left(I_{\max }+I_{\min }\right) \times 100$. When single spots or bars of light increments or decrements were presented to the cells, percentage Weber contrast was defined as $(I-M) / M \times 100$. All recordings were performed at a background in the photopic regime (quantal catch in $\mathrm{R}^{\star}$ /cone/s: L/M-cone, $\sim 13 \times 10^{3}$; S-cone, $\sim 2 \times 10^{3}$ ). Signals were sampled at $10 \mathrm{kHz}$ with an ITC-18 analog-digital board (HEKA Instruments), amplified with a Multiclamp 700B amplifier (Molecular De- vices), and Bessel filtered at $3 \mathrm{kHz}$. All analyses were performed in Matlab (MathWorks).

The conductance analysis was performed using the current responses near the inhibitory $\left(E_{\mathrm{inh}}\right)$ and excitatory $\left(E_{\mathrm{exc}}\right)$ reversal potentials $\left(E_{\mathrm{inh}}\right.$, $\left.-70 \mathrm{mV} ; E_{\mathrm{exc}}, 0 \mathrm{mV}\right)$. The excitatory and inhibitory conductances were then calculated according to established methods (Borg-Graham, 2001; Taylor and Vaney, 2002).

For receptive field measurements, broad thorny receptive fields were modeled as comprising ON and OFF subfields, each with its own centersurround organization. Thus, the ON and OFF fields were each fit with a difference-of-Gaussians (DOG) model using nonlinear regression in Matlab.

Gaussian white noise [30\% root mean square (RMS) contrast] did not modulate the spike output of broad thorny cells enough to obtain conclusive spike-triggered averages (STAs) and output nonlinearities (data not shown). Therefore, a high-contrast binary noise stimulus $(100 \%$ RMS contrast; presentation rate, $60.2 \mathrm{~Hz}$; pseudorandom frame sequence) was used to characterize the kinetic properties of cells. The stimulus was a spot centered on the soma (diameter, 280-360 $\mu \mathrm{m}$ ) and presented on a photopic background (see above). Spot intensity was randomly updated either black or white on every frame. The STA and output nonlinearity were determined using standard methodology (Chichilnisky, 2001). The STA for each cell was normalized by the absolute value of the peak.

For moving stimuli, the speed values are provided in degrees of visual angle per second. Recordings were performed at distances ranging from 5 to $12 \mathrm{~mm}$ away from the foveal pit, which corresponds to an eccentricity range of $\sim 22-\sim 55^{\circ}$ of visual angle. The conversion from micrometers per second of the stimulus to degrees per second as its representation on the retina is based on measurements taken from eyes and retinas of Old World monkeys, including macaques, where it was shown that $1^{\circ}$ of visual angle corresponds to a distance of $190-210 \mu \mathrm{m}$ on the retina (Perry and Cowey, 1985). Thus, a mean value of $200 \mu \mathrm{m}=1^{\circ}$ visual angle was used here for the calculation of stimulus motion speeds.

We modeled the speed tuning to the moving spots (see Fig. 8) as a modified second-order bandpass function, where speed was substituted for frequency:

$$
H_{\text {bandpass }}(s)=k \frac{\left(\frac{s}{s_{0}}\right)}{\left(\frac{s}{s_{0}}\right)^{2}+\frac{\beta_{s}}{s_{0}^{2}+1}}
$$

where $k$ is the maximal gain of the bandpass function, $s_{0}$ is the center speed of the function, and $\beta$ is the bandwidth.

Immunostaining and confocal microscopy. Specimens were immersion fixed in $4 \%$ paraformaldehyde in $0.1 \mathrm{~m}$ phosphate buffer (PB), $\mathrm{pH} 7.4$, for $30-50 \mathrm{~min}$ at room temperature (RT). Following fixation and washing in $\mathrm{PB}$, retinas were cryoprotected in a sucrose solution $(30 \% \mathrm{w} / \mathrm{v})$ and stored at $-20^{\circ} \mathrm{C}$ until use.

If cells were injected with Lucifer yellow, polyclonal rabbit anti-Lucifer yellow antibodies (1:200; Invitrogen A-5750) were used to enhance the intrinsic Lucifer yellow fluorescence using an indirect method with secondary antibodies conjugated to DyLight 488 (see below). Polyclonal goat antibodies against choline acetyltransferase (ChAT, 1:200; Millipore AB144P) were applied as a marker for starburst amacrine cells (Rodieck and Marshak, 1992; Yamada et al., 2003). Retinal wholemounts were incubated freely floating for $3 \mathrm{~d}$ at RT or for $\leq 6 \mathrm{~d}$ at $4^{\circ} \mathrm{C}$ with primary antibodies in $5 \%$ normal donkey serum, $1 \%$ bovine serum albumin, and $1 \%$ Triton X-100 in PB. After washing in PB, secondary donkey antibodies conjugated to DyLight 488 (Jackson ImmunoResearch), DyLight 594 (Jackson ImmunoResearch), or Alexa 633 (Invitrogen) were applied for $3 \mathrm{~h}$ at RT at a dilution of 1:300 (Alexa 633) or 1:500 (all remaining secondary antibodies) together with DAPI (1:2000, Invitrogen). If cells were injected with neurobiotin, Alexa-488-coupled or Alexa-568coupled streptavidin (1:1000, Invitrogen) was added to the mixture of secondary antibodies. For subsequent imaging, specimen were mounted on glass slides in Vectashield mounting medium (Vector Laboratories) and coverslipped with common cover glass. Additional spacers (small 


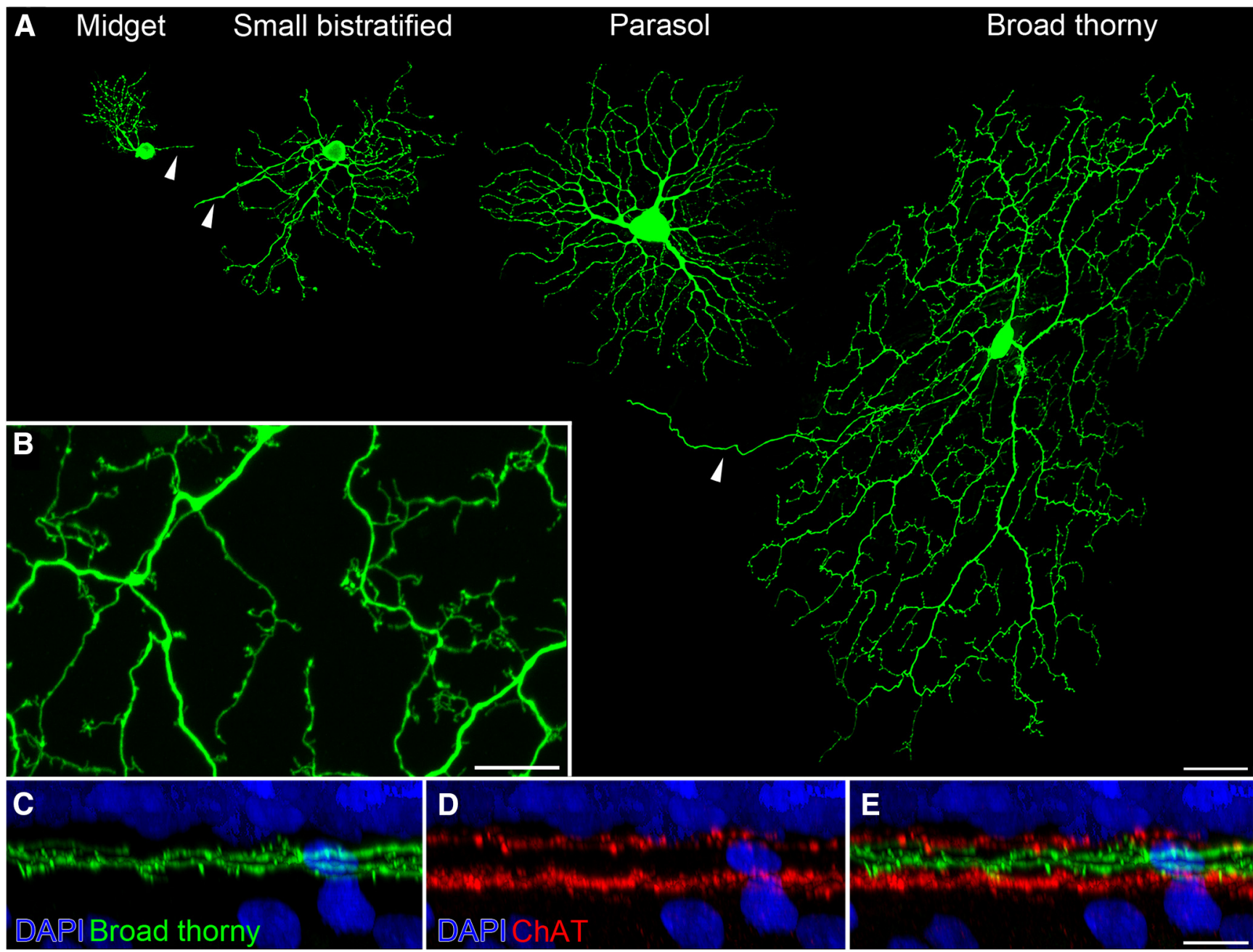

Figure 1. Morphology of broad thorny ganglion cells. $A, A n O N$ midget, a small bistratified, an $0 N$ parasol, and a broad thorny ganglion cell are shown. Cells were injected with Lucifer yellow at similar retinal eccentricities. Maximum intensity projections of confocal image stacks were separately produced and assembled for this image. Arrowheads point to the axons of the cells. $\boldsymbol{B}$, Magnification of a broad thorny cell's dendritic tree (z-projection). $C-E$, Lucifer-yellow-injected broad thorny cells were counterstained in whole-mounted tissue with DAPI to label cell nuclei and antibodies against ChAT to label starburst amacrine cells. An xy-projection of a magnified area from a broad thorny cell's dendritic field is shown. Scale bars: $A, 50 \mu \mathrm{m} ; \boldsymbol{B}, \boldsymbol{E}, 10 \mu \mathrm{m}$.

pieces of cover glass) were placed between the slide and cover glass to prevent the tissue from being squeezed.

Images were taken using an Olympus FV1000 confocal microscope. Overview scans were acquired with either $10 \times /$ air or $20 \times /$ oil-immersion objectives. For dendritic field measurements in a Fiji distribution of ImageJ (http://fiji.sc/), individual stacks from overview scans were collapsed into a single plane (maximum intensity $z$-projection). The dendritic tree was outlined with a polygon encompassing all distal tips. Given the noncircular shape of broad thorny ganglion cell dendritic trees, the average of maximum and minimum Feret diameters of the polygon was calculated per cell to provide a better estimate of the actual dendritic field size. High-resolution scanning of image stacks was performed using an Olympus UPlanSApo $60 \times / 1.35$ oil-immersion objective with $\geq 800 \times 800$ pixels and a $z$-axis increment of $\leq 0.3 \mu \mathrm{m}$ for $x y$-projections of image stacks in ImageJ. Brightness and contrast of the final images were adjusted using Adobe Photoshop.

\section{Results}

Morphology of broad thorny ganglion cells

Functional and morphological data are available for the highdensity and moderate-density primate ganglion cell types, such as midget, parasol, and small bistratified ganglion cells (Fig. 1A). These cell types comprise $\sim 75 \%$ of the total ganglion cell population in peripheral macaque retina and are frequently targeted in in vitro preparations of primate retina (Dacey, 2004). Functional investigations of other human and nonhuman primate ganglion cell types are scarce due to limited resources and the challenge to selectively target low-density cell types for analysis. Broad thorny ganglion cells belong to the family of low-density cell types, representing only $\sim 1 \%$ of the total ganglion cell population (Dacey, 2004).

Here, we identified broad thorny ganglion cells by their characteristic response pattern in extracellular recordings (see below). The identity was further confirmed by subsequent imaging of the dye-injected cells (Fig. $1 A$ ). Two or three primary dendrites emanated from the soma (mean \pm SD soma diameter, $18 \pm 2$ $\mu \mathrm{m} ; n=7$ ) and gave rise to a fairly dense dendritic meshwork with multiple branch points. The dendritic field size of $21 \mathrm{com}-$ pletely filled cells was $369 \pm 63 \mu \mathrm{m}$ (mean \pm SD). Secondary dendrites and branchlets were often recurving, filling out most spaces homogenously within the dendritic field without much overlap. The dendrites and their branchlets exhibited many spine-like processes (Fig. 1B). They ascended and descended throughout the center of the IPL, spanning both ON and OFF compartments between the ChAT-labeled bands of ON and OFF starburst amacrine cells (Fig. $1 C-E$ ). Very occasionally, single 
A
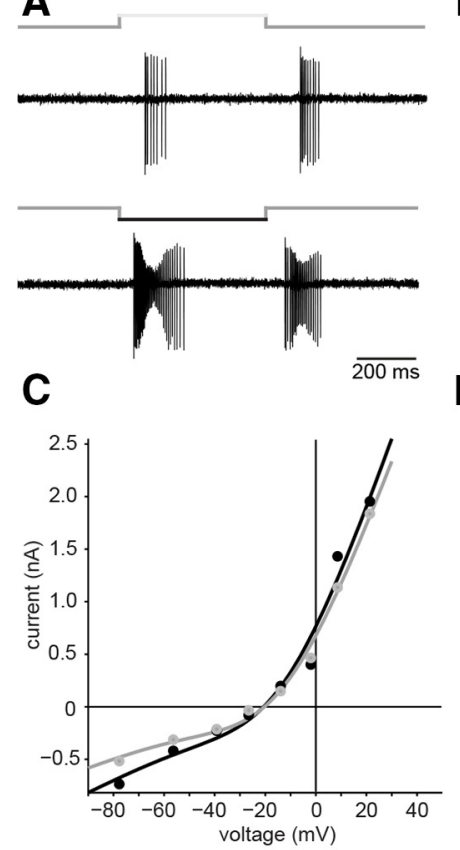

B

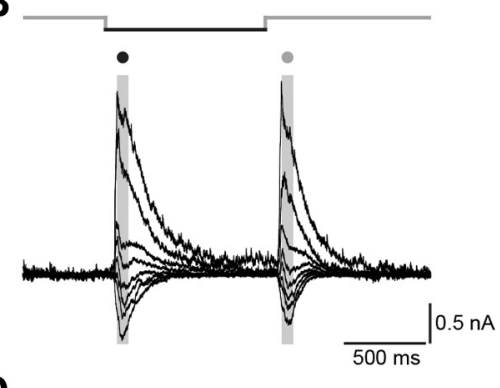

$\mathbf{F}$

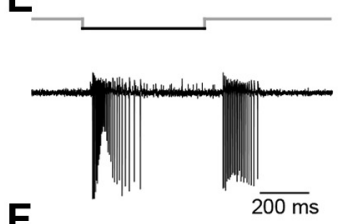

D

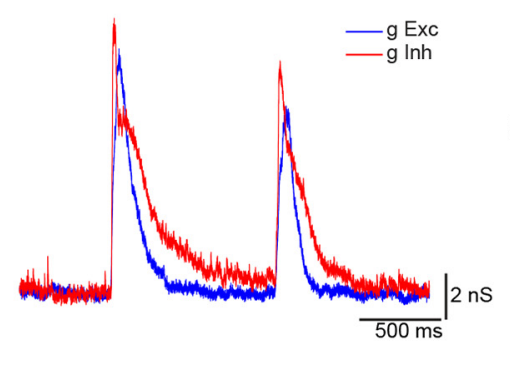

E
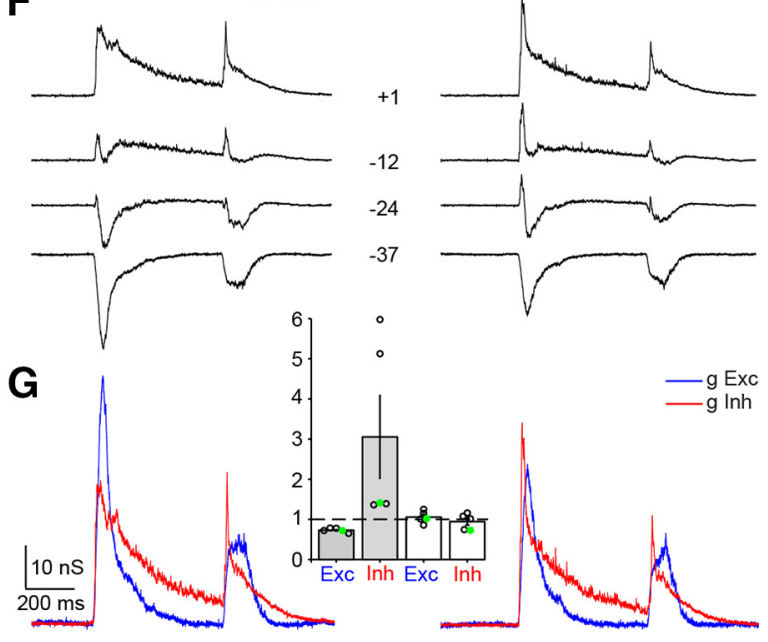

Figure 2. Response properties of the receptive field center. $A$, Spike responses of a broad thorny cell upon stimulation with light increments (top) or decrements (bottom) from a gray background. $B$, Whole-cell voltage-clamp recordings of the same cell to light decrements at eight different holding potentials (ranging from -78 to $+21 \mathrm{mV}$ ). Gray bars with black and gray circles on top indicate sampling areas for the $(\boldsymbol{C})$ current-voltage relationships of the $\mathrm{OFF}$ or the $\mathrm{ON}$ phase of the light response, respectively. $\boldsymbol{D}$, Excitatory (blue) and inhibitory (red) conductances calculated from the whole-cell current responses (in B). E, Spike response of a cell to the first (left) and last (right) stimulus during a set of three subsequent pulses (light decrements). Pulse durations were $500 \mathrm{~ms}$; time between individual pulses was $1.5 \mathrm{~s}$. $F$, Whole-cell voltage-clamp responses at four selected holding potentials from -37 to $+1 \mathrm{mV}$. Example traces were chosen around the reversal potential of the synaptic currents where the differences between first and last set became most obvious. $\mathbf{G}$, Conductance analysis of the corresponding current responses (holding potentials in full set of measurements ranged from -55 to $+14 \mathrm{mV}$ ). For the $0 \mathrm{FF}$ phase of the response, the peak excitatory conductance in the last trial was reduced to $65 \%$ relative to the initial trial; the peak inhibitory conductance was increased to a total of $141 \%$. Data points of the analyzed cells $(n=5)$ are shown in the inset; the example cell values are shown in green (gray bars, $0 \mathrm{FF}$ phase; white bars, $0 \mathrm{~N}$ phase of the light response; error bars represent 1 SEM). Data points above or below the dashed line represent a relative increase or decrease of the conductance between first and last trials, respectively.

branchlets were observed ascending farther toward the inner nuclear layer (data not shown).

\section{Basic ON-OFF response properties}

We probed the basic response properties of broad thorny cells by recording spikes extracellularly while presenting increment or decrement spots to the receptive field center $(100 \%$ contrast on a gray background; Fig. 2A). Spike bursts were elicited at the onset and at the offset of each stimulus. Thus, broad thorny cells are ON-OFF center ganglion cells, consistent with their stratification level within the IPL. The OFF phase of the light response was usually stronger than the ON phase. Dark spots caused the overall strongest spike discharge, leading to an hourglass-shaped spike height modulation upon initial presentation. No maintained baseline spike rate was observed in the dark or during periods of uniform background illumination.

We performed whole-cell voltage-clamped recordings $(n=$ 10) to elucidate the synaptic origins of the light response (Fig. $2 B)$. Cells were clamped at increasing holding potentials between -80 and $+30 \mathrm{mV}$ while the receptive field center was stimulated with decrement spots from a gray background. ON-OFF responses of broad thorny cells were reflected in both excitatory and inhibitory synaptic input currents. The current-voltage relationships had a similar appearance for both $\mathrm{ON}$ and OFF phases of the response (Fig. 2C). The conductance analysis revealed a strong and immediate inhibitory input to the cells (Fig. 2D), which usually exceeded the excitatory conductances in strength and duration.

A decrease of the spike response strength was observed in all recorded cells during repeated stimulation. Figure $2 E$ shows a cell's spike response to the first and last pulse of three subsequently presented stimuli (pulse duration, $500 \mathrm{~ms}$; $1.5 \mathrm{~s}$ interval between individual pulses). The corresponding whole-cell currents and conductance analyses for the same cell are shown below (Fig. $2 F, G$ ). The inhibitory inputs to the cell increased while the excitatory input decreased in the OFF phase of the light response. We measured the peak conductances of excitatory and inhibitory currents $(n=5)$ for both ON and OFF phases of the light response and determined the relative change between the first and last stimulation (Fig. $2 G$, inset; green circles represent data points of the example cell presented here). During the last stimulus in a set of three, the peak excitatory OFF conductance was reduced to $73 \pm 2 \%$ (mean \pm SEM) when compared with the conductance during the first trial. However, the OFF inhibition increased to $305 \pm 103 \%$ of the initial peak. Only minor changes of the ON conductances occurred when the first and last trials were compared (excitation, $106 \pm 7 \%$; inhibition, $94 \pm 9 \%$ ).

\section{Comparison to other ON-OFF cells in the center IPL}

Two other putative ON-OFF cells are known to stratify in the center of the IPL. Dendrites of recursive bistratified ganglion cells were shown to narrowly stratify at the outer and inner borders of the space that broad thorny cells occupy (Dacey, 2004), but light responses of this cell type have not been previously reported. This region also contains dendrites of the Al amacrine cell, a spiking, polyaxonal ON-OFF center amacrine cell with known morphological and physiological properties (Stafford and Dacey, 1997; Davenport et al., 2007; Greschner et al., 2014). Here, we recorded spike responses of broad thorny $(n=5)$ and recursive bistratified 

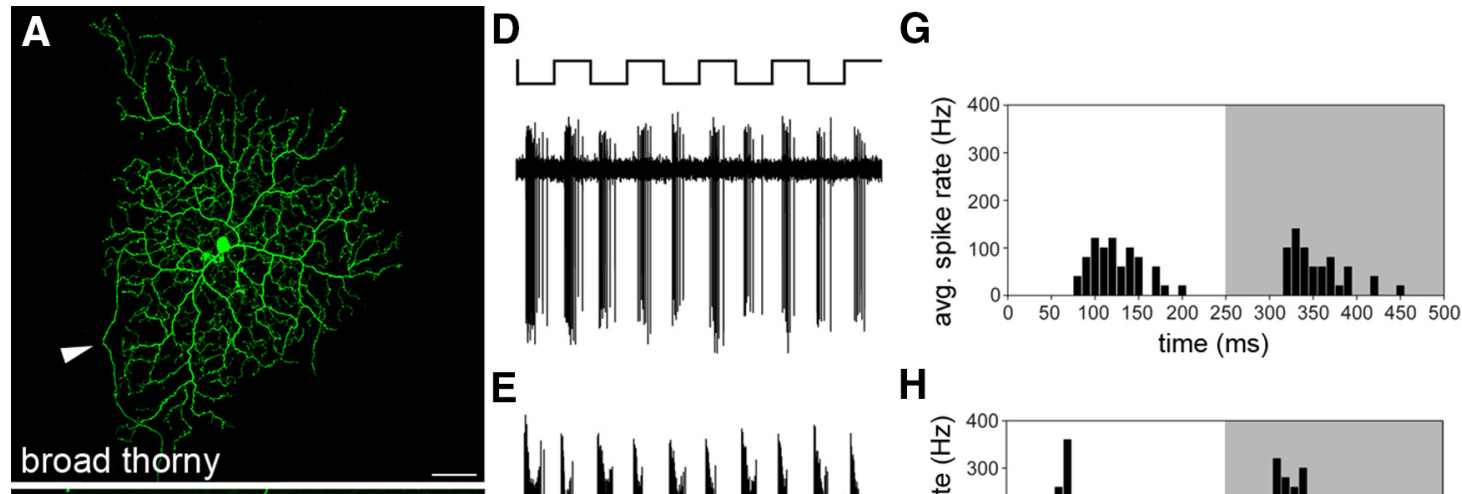

E

H
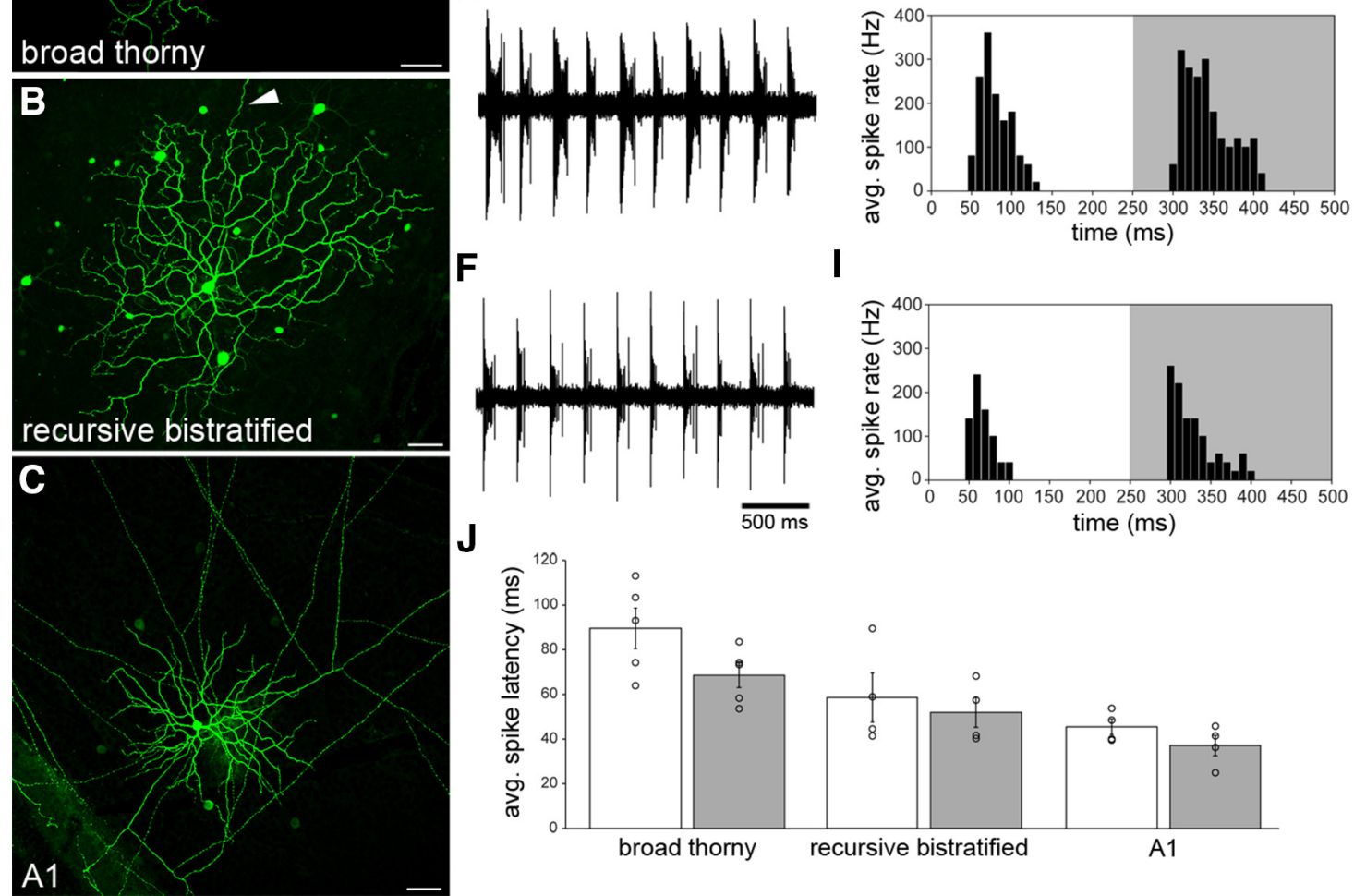

Figure 3. Broad thorny cell light responses in comparison with other $\mathrm{ON}-\mathrm{OFF}$ cells. $A-C$, Maximum intensity projections of confocal image stacks of a broad thorny ganglion cell injected with Lucifer yellow $(\boldsymbol{A})$, a recursive bistratified ganglion cell injected with neurobiotin $(\boldsymbol{B})$, and an $A 1$ amacrine cell injected with Lucifer yellow (C). Arrowheads in $\boldsymbol{A}$ and $\boldsymbol{B}$ point to the axons of the ganglion cells. Several tracer-coupled somata appeared after neurobiotin injection and streptavidin labeling of recursive bistratified cells. In A1 amacrine cells, multiple straight axons (cropped at edges of the image) were observed, emanating from the circular-shaped dendritic field in the center of the image. Faintly labeled, tracer-coupled somata were also observed after injecting $\mathrm{A} 1 \mathrm{amacrine}$ cells with Lucifer yellow. Scale bars, $50 \mu \mathrm{m}$. D-F, Corresponding spike responses of the cells shown in $\mathbf{A}-\mathbf{C}$ to a $2 \mathrm{~Hz}$ square-wave modulated spot presented to the receptive field center. G-I, Binned spike rate of the same cells as a function of time, averaged across the five stimulus cycles shown in $\boldsymbol{D}-\boldsymbol{F}$. The white and gray backgrounds indicate $0 \mathrm{~N}$ and 0 FF phases of the light response, respectively. $J$, Spike latency of ON (white) and OFF (gray) phases of light responses measured in five broad thorny cells, four recursive bistratified ganglion cells, and four A1 amacrine cells. Error bars represent 1 SEM.

$(n=4)$ ganglion cells as well as A1 amacrine cells $(n=4$; Fig. $3 A-C)$ to directly compare their light responses. The cells were stimulated with a square-wave modulated spot on a gray background. The spot was centered on the receptive field of each cell and adjusted in size to elicit the most robust responses. ON and OFF spike trains with characteristic discharge patterns occurred in all three cell types upon stimulation (Fig. 3D-F). After averaging the spike response over five stimulus cycles per cell, a delay of broad thorny cell light responses relative to those of the other cell types was observed (Fig. 3G-I). We measured the spike latency as the time to first spike after the stimulus transition (from black to white or vice versa) and averaged the values across five stimulus cycles per cell. Both ON and OFF phases of broad thorny cell light responses had the longest spike latency among the three investigated cell types (Fig. 3J; mean \pm SEM: broad thorny: ON, $90 \pm 9$ $\mathrm{ms}$; OFF, $69 \pm 6 \mathrm{~ms}$; recursive bistratified: ON, $59 \pm 11 \mathrm{~ms}$; OFF, $52 \pm 7 \mathrm{~ms} ; \mathrm{Al}: \mathrm{ON}, 46 \pm 4 \mathrm{~ms}$; OFF, $37 \pm 5 \mathrm{~ms})$.

\section{Response kinetics}

Spatially uniform, temporal noise was used to further investigate the response properties of broad thorny cells and to compare the kinetics with a more familiar primate ganglion cell type, the parasol cell. A binary noise stimulus (100\% RMS contrast; presentation rate, $60.2 \mathrm{~Hz}$; pseudorandom frame sequence), produced robust STAs and nonlinearities from both broad thorny cells $(n=6)$ and ON parasol cells $(n=4$; Fig. 4$)$.

ON parasol ganglion cells are known to exhibit fast, transient kinetics (Benardete and Kaplan, 1999; Chichilnisky and Kalmar, 2002), which was also observed in the present study (Fig. 4A,B). The average STA from four ON parasol cells (blue) showed the expected positive deflection and a characteristic biphasic quality. The STA peaked $40.5 \pm 2.1 \mathrm{~ms}$ (mean $\pm \mathrm{SD}$ ) preceding the average spike and crossed through zero at $65.4 \pm 16.2 \mathrm{~ms}$. The broad thorny STA (red) exhibited a negative deflection and was markedly slower than the $\mathrm{ON}$ parasol cell, peaking at $65.7 \pm 16.1$ 

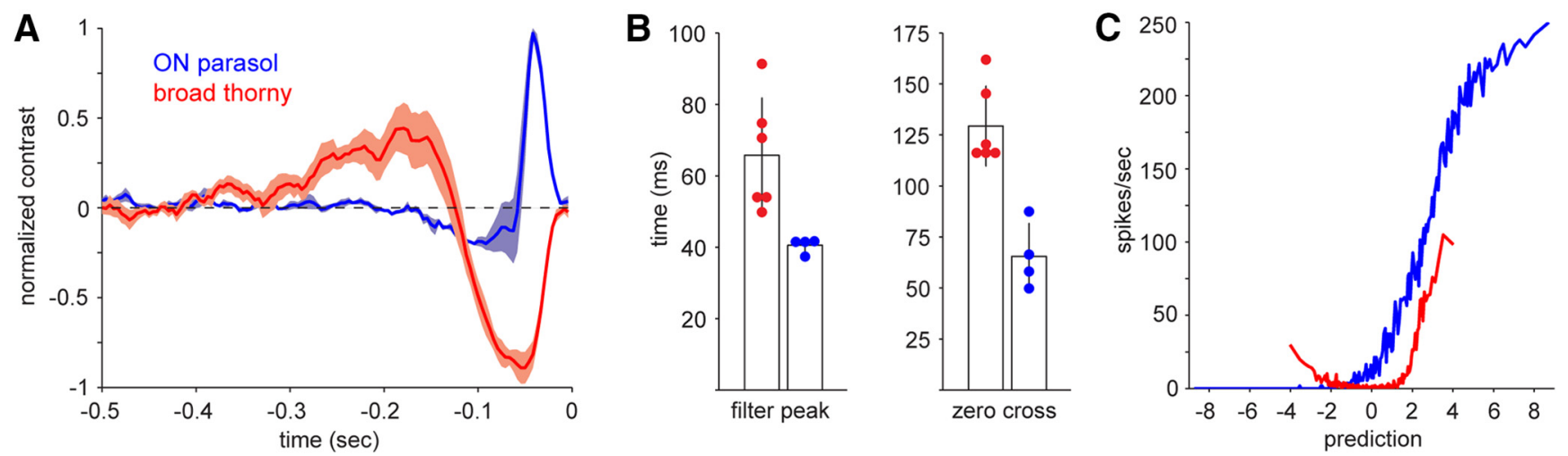

Figure 4. Temporal kinetics of the light response. $A$, Mean spike-triggered averages (linear filters) for broad thorny cells (red, $n=6$ ) and ON parasol cells (blue, $n=4$ ). The STA for each cell was normalized by the absolute value of the peak. Shaded areas represent 1 SEM. ON parasol cells exhibit faster kinetics than broad thorny cells. B, Summary of kinetic properties. Filter (STA) peaks were faster for $\mathrm{ON}$ parasol cells (blue) than for broad thorny cells (red). Individual cells are indicated by circles. The zero-cross was likewise shorter for ON parasols than for broad thorny cells. Error bars indicate mean \pm SD. C, Example output nonlinearities of an $0 \mathrm{~N}$ parasol and a broad thorny ganglion cell. The $x$-axis indicates linear prediction generated by convolution of the STA with the stimulus. The $y$-axis shows the actual spike output of the cells.

ms. In addition, the broad thorny STA crossed zero at $129.4 \pm$ $19.5 \mathrm{~ms}$. These filter properties are consistent with preceding data (Fig. 3) and further support the notion that broad thorny cell response properties are characterized by relatively slow kinetics in our experimental conditions. The striking differences between parasol and broad thorny response properties were also obvious from their output nonlinearities (Fig. 4C). The nonlinearities were computed by convolving the STA (i.e., linear filter) with the frame sequence to produce a linear prediction. Then, we plotted that prediction versus the observed spike output of the cell (Chichilnisky, 2001). A representative example of an ON parasol output nonlinearity exhibited a sigmoid shape typical for this type of ganglion cell. An example of a broad thorny nonlinearity was "U"-shaped, consistent with an ON-OFF cell.

Given that broad thorny cells are ON-OFF center cells, we attempted a separation of the $\mathrm{ON}$ and OFF temporal components by performing a principal components analysis (PCA) on the data obtained from these experiments. However, the nonlinearities for the corresponding PCA filters were both U-shaped, indicating that the PCA filters did not cleanly identify ON and OFF response components (data not shown). Nevertheless, the PCA did not reveal any faster response components of broad thorny cell responses.

\section{Center-surround responses}

Next, we focused on the spatial properties of broad thorny cells' receptive fields by presenting square-wave modulated spots on a gray background. The spot diameter changed randomly to values between 90 and $900 \mu \mathrm{m}$. Figure $5 A$ shows the binned $O N$ and OFF spike responses of a cell, averaged across five stimulus cycles per spot diameter. Overall, light responses were relatively weak or absent (particularly in the ON phase) at the smallest spot diameters and became stronger with increasing spot size. However, spot sizes reaching the mean dendritic field size and beyond suppressed the light responses. We fitted the data of each individual cell with a DOG function (data not shown). The data of both ON and OFF phases were fit well with this function in 9 of 14 cells (peak mean \pm SD: ON, $287 \pm 64 \mu \mathrm{m}$; OFF $281 \pm 67 \mu \mathrm{m}$ ). Next, we normalized the mean spike rates by their peak and averaged these values across all cells (Fig. $5 B ; n=14$ ). The average data were fit well with a DOG function (solid lines: peak ON, $325 \mu \mathrm{m}$; peak OFF, $303 \mu \mathrm{m}$ ). Here, the spike responses and fits peaked near the average dendritic tree diameter (dashed line, $369 \mu \mathrm{m}$ ).
We determined the surround suppression index of $\mathrm{ON}$ and OFF response phases for each cell as a measure of the peak response relative to the response elicited at largest spot sizes ( 1 , full suppression; 0, no suppression; Fig. 5C). The surround suppression index of $0.86 \pm 0.04$ (mean $\pm \mathrm{SEM}$ ) for the $\mathrm{ON}$ phase was larger than $0.62 \pm 0.09$ for OFF. The ON response was completely suppressed by large stimuli in 6 of 15 cells.

We presented the same stimulus paradigm to cells also during whole-cell voltage-clamp recordings to elucidate the underlying synaptic currents of this particular, spot-sizedependent spike response pattern of broad thorny cells. The cells were clamped close to the reversal potential for chloride or cations to isolate the excitatory or inhibitory synaptic inputs, respectively. Figure $6 \mathrm{~A}$ shows another example of a broad thorny cell, exhibiting either OFF or ON-OFF spike responses, depending on the stimulus size (black, top row) as described above. In the same cell, measurement of the lightevoked, excitatory currents (exc, blue, middle row) revealed negligible excitatory inputs to the cell during the ON phase of the small-diameter spots. Small excitatory inputs occurred during the OFF phase (left column).

The inhibitory currents (inh, red, bottom row) followed the same pattern during this stimulus condition. Intermediate spot sizes (middle column) elicited robust ON-OFF spike responses and correspondingly strong ON and OFF excitatory currents. These currents were fairly balanced in size during both stimulus phases. Similarly strong and balanced inhibitory currents were observed. At a large spot size (right column), spiking was completely suppressed in the ON phase, partially in OFF. Interestingly, the excitatory currents were strongly decreased relative to the currents elicited by the intermediate spot size. However, the inhibitory input to the cell increased or reached a plateau in the $\mathrm{ON}$ or OFF phase of the response, respectively.

The complete area-response functions substantiate these findings. The normalized peak currents for excitatory (Fig. $6 B$; $n=10$ ) and inhibitory (Fig. $6 C ; n=7$ ) synaptic inputs to broad thorny cells are shown as a function of spot diameter. Thus, presynaptic suppression of the excitatory inputs is combined with a persistently strong inhibitory input during stimulation of broad thorny cells well outside of their receptive field centers. This result helps explain the diminished spike output when large, stationary stimuli were used. 

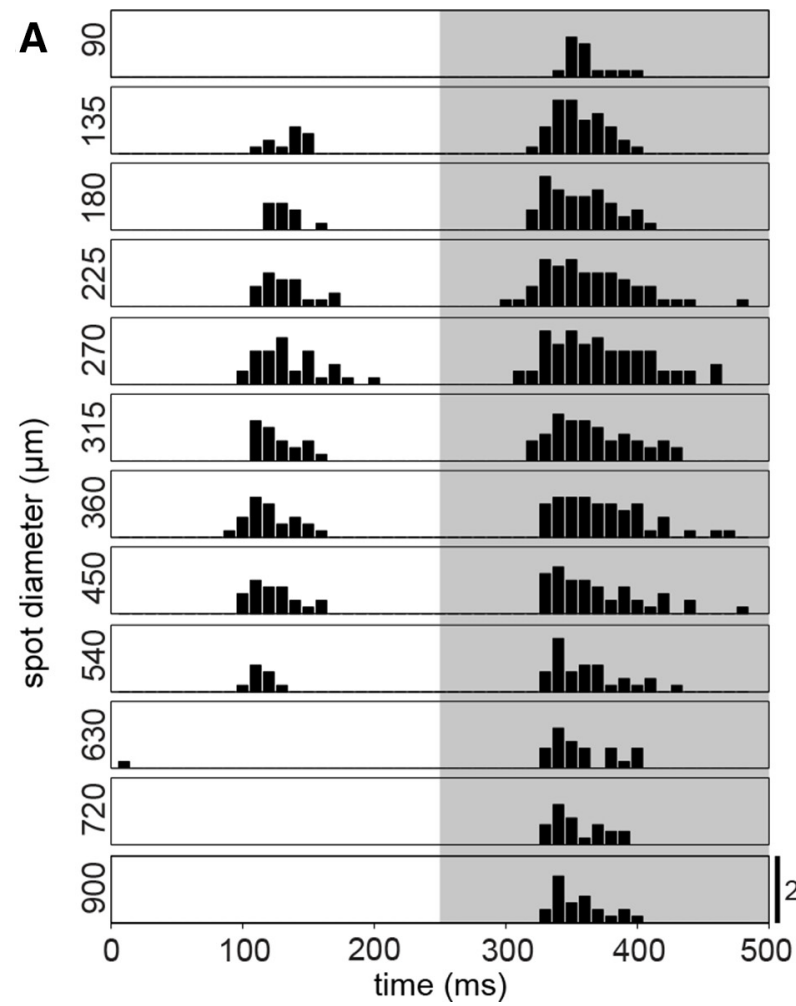

B

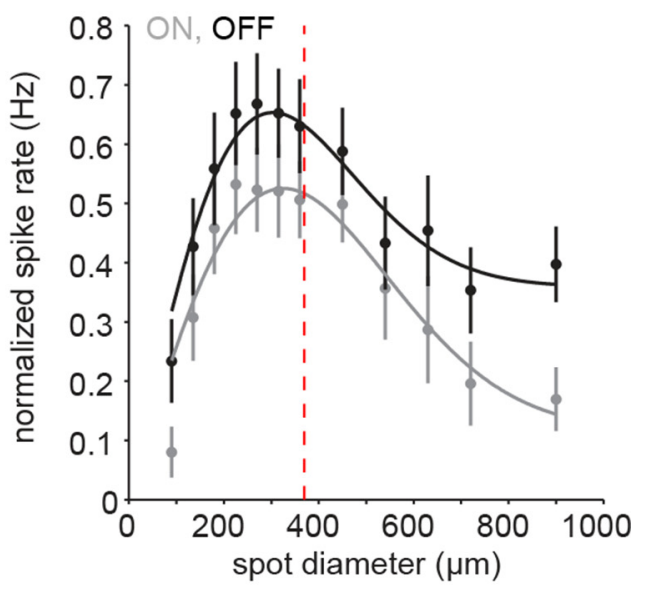

C

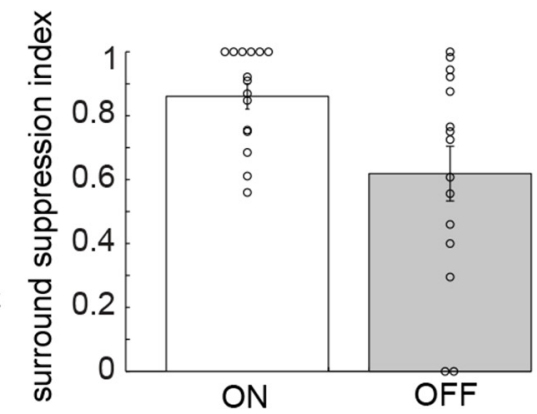

Figure 5. Spatial properties of the receptive field. $A$, Binned spike rate (spikes per second) of a broad thorny ganglion cell to a $2 \mathrm{~Hz}$ square-wave modulated spot at different spot diameters. The height of each box indicates a spike rate of $200 \mathrm{~Hz}$. The spike response was averaged across five stimulus cycles. $\boldsymbol{B}$, Mean spike rate of 15 cells to the stimulus as in $\boldsymbol{A}$ as a function of spot diameter, averaged across half the stimulus cycle $(250 \mathrm{~ms})$ and normalized to the peak spike rate per cell. Error bars represent 1 SEM. Solid lines indicate DOG fit of the data; dashed line indicates the mean dendritic field size. C, Surround suppression index of the cells included in $\boldsymbol{B}$ for the $\mathrm{ON}$ and $0 \mathrm{FF}$ phases of the response. The index indicates the strength of the surround suppression of the cell's peak response elicited by increasing spot sizes (1, full suppression; 0 , no suppression).
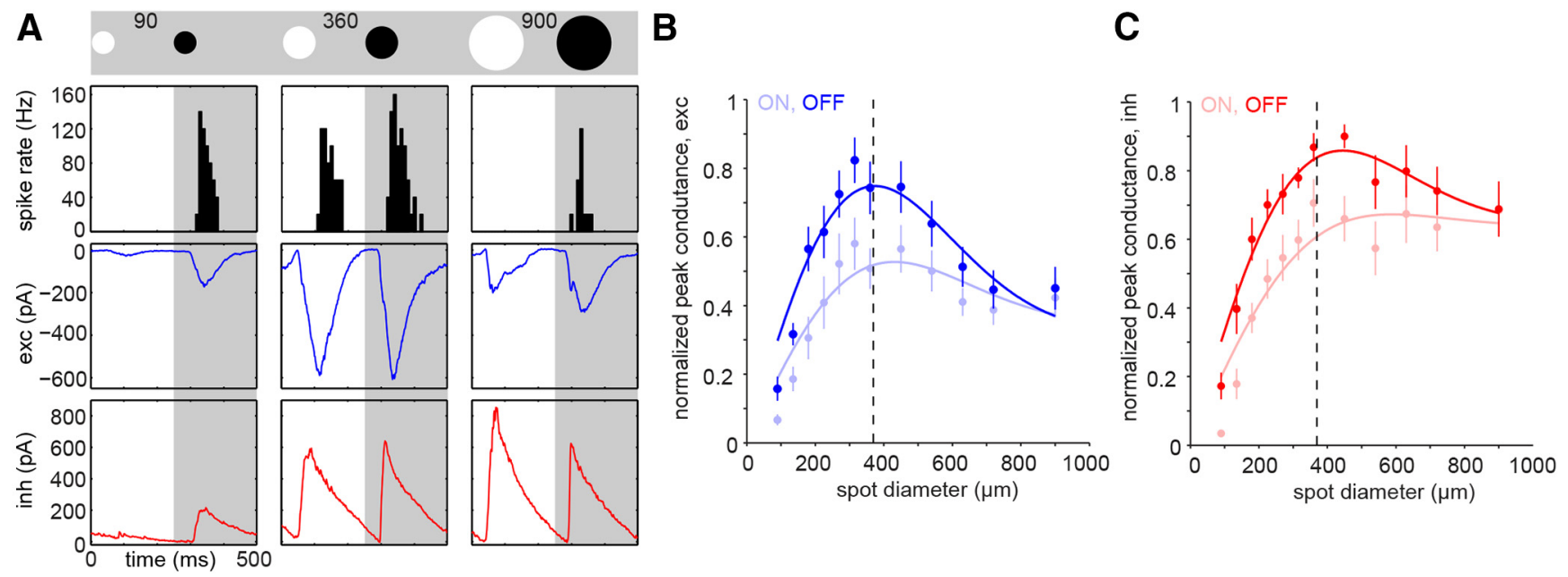

Figure 6. Synaptic inputs shaping the spike responses. A, The stimulus was a $2 \mathrm{~Hz}$ square-wave modulated spot at different spot diameters (90, 360, $900 \mu$ m; schematic on top). Top row, Binned spike rate (black) of a broad thorny cell to the stimulus indicated above the figure panel. Middle row, Excitatory currents (exc, blue) of the same cell. Bottom row, Inhibitory currents (inh, red). All responses were averaged across five stimulus cycles. Each box width indicates $500 \mathrm{~ms}$. B, C, Normalized peak currents of excitatory (blue, $n=10$ ) and inhibitory (red, $n=7$ ) synaptic inputs to broad thorny cells as a function of spot diameter during ON and OFF phases of the light response. Error bars represent 1 SEM. Solid lines indicate DOG fits of the data, dashed line indicates the mean dendritic field size.

\section{Moving stimuli}

It remains unclear whether the primate retina contains ganglion cells selectively tuned to the direction of a moving stimulus, similar to the well known direction-selective cells of other species (Barlow and Hill, 1963; Weng et al., 2005) reviewed by Vaney et al. (2012). We tested for putative direction selectivity of broad thorny ganglion cells by moving a white bar on a black back- ground across the cell's receptive field at 8 or 12 different angles $\left(4-8^{\circ}\right.$ per second; $\left.n=9\right)$. This stimulus elicited a vigorous spike discharge when the leading edge of the bar entered the receptive field (ON response) and when the trailing edge left the receptive field (OFF response), independent of the direction of motion (Fig. 7A). Interestingly, the spike response caused by the moving edges of the bar was stronger than the one observed with similar, 
A
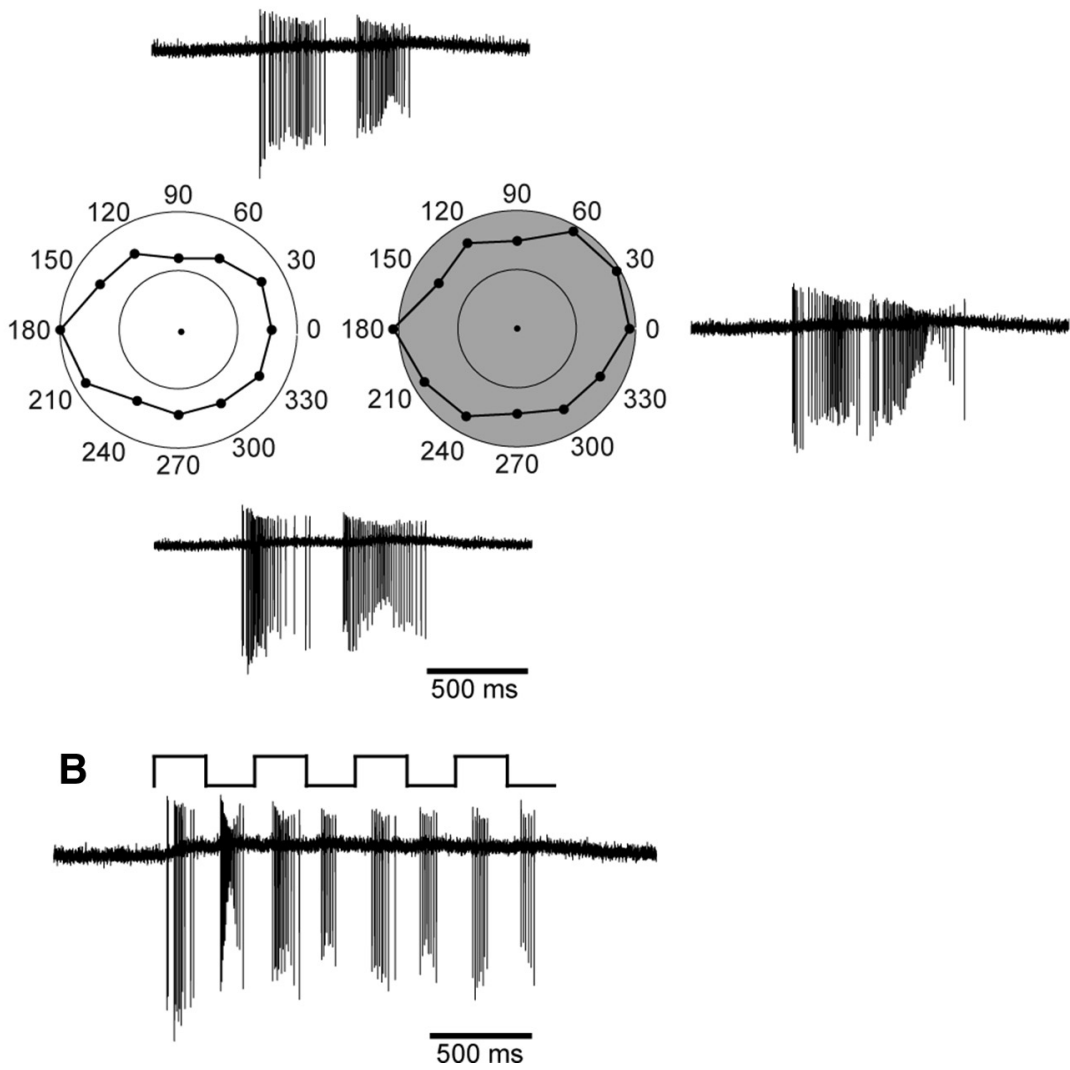

Figure 7. Light responses are not tuned to the direction of motion. $A$, A white bar ( $504 \mu \mathrm{m}$ length, $126 \mu \mathrm{m}$ width) was moved on a black background across the cell's receptive field at 12 different angles in random order from 0 to $330^{\circ}$, parallel to its long axis. The speed of the bar was $5^{\circ}$ of visual angle per second. The left polar plot (white) shows the mean, binned spike rate (spikes per second) of the cell's $0 \mathrm{~N}$ response to the leading edge of the bar; the $0 \mathrm{FF}$ response to the trailing edge is shown on the right (gray). Inner and outer circles of the plots indicate 50 and 100 spikes/s, respectively. Example traces of the cell's spike response are shown for four bar angles $\left(0^{\circ}\right.$, right; $90^{\circ}$, top; $180^{\circ}$, left; $270^{\circ}$, bottom). $\boldsymbol{B}$, Spike responses of the same cell when a stationary white bar was repeatedly flashed onto the cell's receptive field at $2 \mathrm{~Hz}$ on a black background.
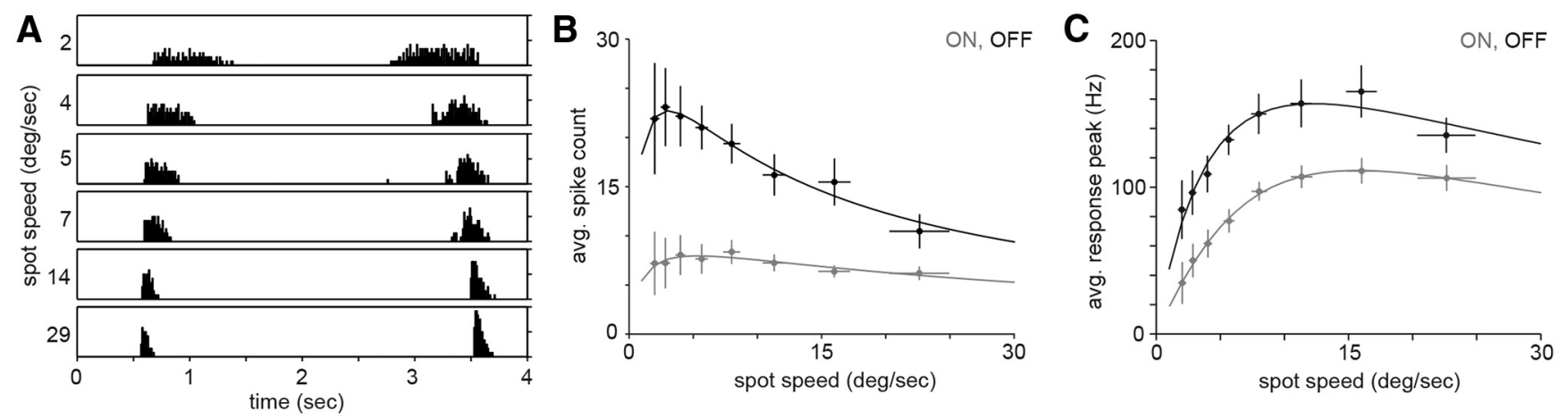

Figure 8. Speed tuning. A, A black spot (360 $\mu \mathrm{m}$ diameter) was repeatedly moved into and out of a cell's receptive field at six different speeds on a gray background. The binned spike rate (spikes per second) of the $0 \mathrm{~N}$ response (left, spot leaving the receptive field) and the $0 \mathrm{FF}$ response (right, spot entering the receptive field) was averaged across seven stimulus cycles per spot speed. The height of each box indicates a spike rate of $200 \mathrm{~Hz}$. B, Spike count per ON and OFF burst elicited by moving black spots, averaged across six stimulus cycles per spot speed in six cells. C, Peak spike rates at different spot speeds, averaged across six stimulus cycles per spot speed in six cells. Data points in $\boldsymbol{B}$ and $\boldsymbol{C}$ were fitted with a second-order bandpass function (solid curves). Gray, 0N response; black, OFF response.

stationary stimuli. For direct comparison, we recorded the spike response from the same cell while the bar was repeatedly flashed onto the receptive field (Fig. $7 B$ ). Note that all spike traces are shown at the same time scale. The stationary white bar was presented at different angles relative to the cell's receptive field to additionally test for a putative preference of broad thorny cells for the orientation of a stimulus ( $n=4$; data not shown). Despite the augmented response to moving stimuli, broad thorny cells were not selective for the direction or the orientation of the stimulus.

The spike response of broad thorny ganglion cells was further investigated by presenting moving spots at different velocities to the cells $(n=6)$. Figure $8 A$ shows the responses of a broad thorny cell to a black spot, which was repeatedly moved into and out of the receptive field on a gray background. Again, spike bursts were elicited when the spot left (ON response) or entered (OFF response) the receptive field. By increasing the motion speed, the spike bursts became more transient and the peak spike rate increased. To quantify the results, we averaged the number of spikes per ON and OFF burst across six repeats of the stimulus and plotted the data as a function of spot speed (Fig. 8B). The 


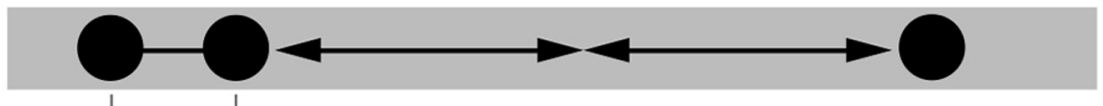

A broad thorny

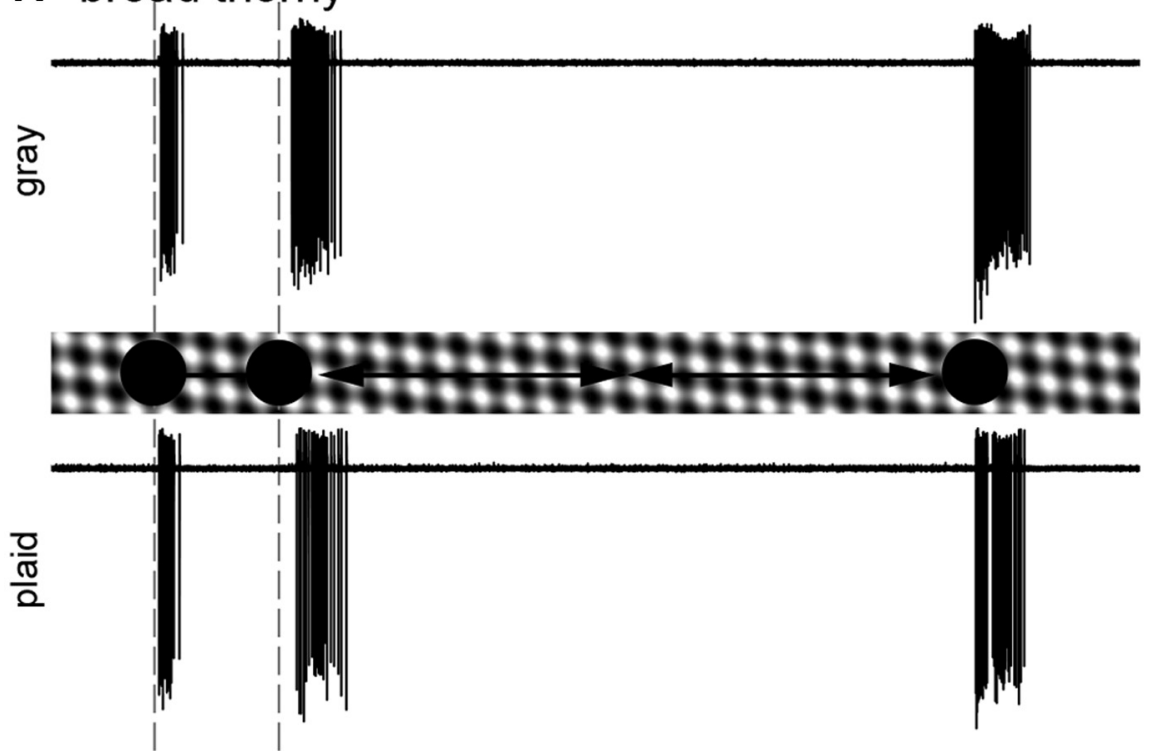

B recursive bistratified

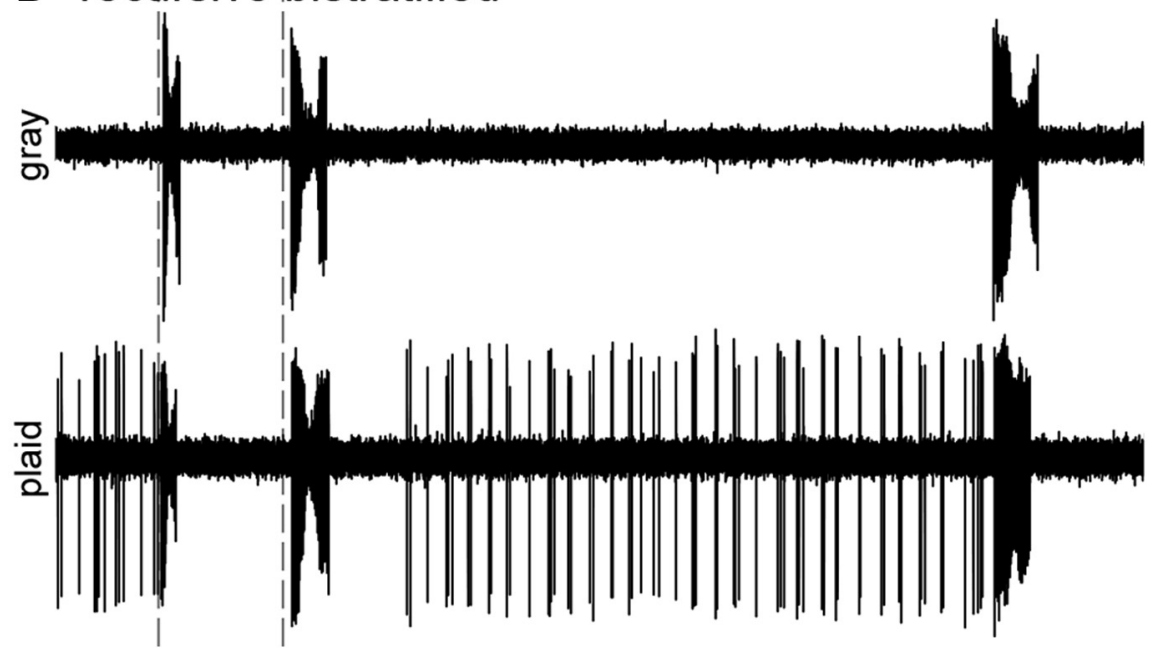

C OFF parasol

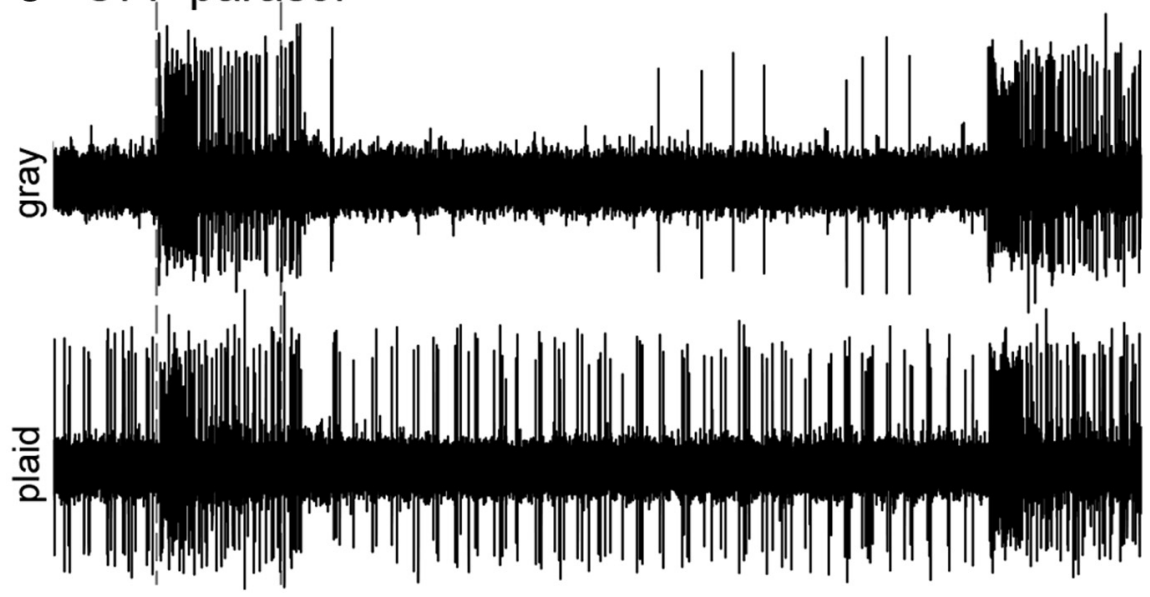

$1 \mathrm{sec}$

Figure 9. Object slip stimulus. The schematics on top of the figure and between the spike traces illustrate the stimuli. The initial presentation of the spot and the onset of its motion are indicated by dashed lines. The background was either uniform gray or a spike count of the ON response stayed relatively stable across the range of tested spot speeds. However, the spike count of the OFF bursts decreased with increasing spot speed and approached the values of ON bursts at the highest speeds. A similar analysis of the peak spike rates (Fig. 8C) revealed a trend toward increased spike rates at spot speeds beyond $\sim 10^{\circ}$ per second. Overall, the cells were rather broadly tuned to respond to slow-moving as well as fast-moving objects.

The apparent preference of broad thorny cells for moving objects-together with the superior colliculus as one of their brain target areas (Rodieck and Watanabe, 1993; Dacey, 2004)—suggested a role of these cells in triggering saccades during eye movements in certain conditions (see Discussion). To test the putative behavior of broad thorny cells while the eye is tracking an object, we presented a black spot on a gray background to the broad thorny cell's receptive field (Fig. 9A, upper trace, first spike burst). Subsequently, we moved the spot away from the receptive field (second spike burst) and then back to its original position (third spike burst) to simulate a deviation of the object from its trajectory $(n=13)$. The spot speed varied between experiments at a range from 4 to $8^{\circ}$ per second. Again, the motion of the spot caused a stronger spike discharge than at the onset of the initial presentation.

Because the background of a visual scene is constantly in motion during eye movements, the spot was also presented in combination with a continuously moving plaid pattern used as the background stimulus (Fig. 9A, lower trace). The moving, sinusoidal modulated plaid did not elicit any spiking activity, and the basic response pattern stayed the same when compared with the responses at a gray background. Experiments were repeated with a white spot, yielding similar results (data not shown).

drifting plaid pattern. A, Top trace, A black spot (360 $\mu \mathrm{m}$ diameter) was flashed onto the receptive field of a broad thorny cell on a gray background, evoking a spike response in the cell (first spike burst on the left). The spot was moved away from the cell's receptive field at a speed of $4^{\circ}$ of visual angle per second (second spike burst). A third spike burst was elicited when the spot returned into the cell's receptive field. Bottom trace, The stimulus was repeated while the gray background was replaced with a full-field, sinusoidal plaid pattern (black and white bars, $70 \mu \mathrm{m}$ bar width, $100 \%$ local contrast, $0 \%$ mean contrast across the full stimulus presentation). The plaid moved continuously at a speed of $4^{\circ}$ visual angle per second. $\boldsymbol{B}$, $C$, The same sets of stimuli were presented to a recursive bistratified cell ( $\boldsymbol{B}$ ) and an OFF parasol ganglion cell $(\boldsymbol{C}$. 
We used the same stimulus paradigm on recursive bistratified cells (Fig. $9 B ; n=4)$ and on ON and OFF $(n=6)$ parasol cells (Fig. 9C; ON parasol data not shown). The overall response pattern of recursive bistratified cells was similar to broad thorny cells when using the gray background. However, the spike output was strongly modulated during the phases where the plaid was presented to the receptive field (and not covered by the spot). In OFF parasol cells, a sustained response was observed during the initial presentation of the spot until it was moved away from the receptive field. Another sustained response was elicited upon the return of the spot. A weak maintained spike rate was observed at a gray background, while the moving plaid directly evoked spiking activity in these cells, similar to what was observed in recursive bistratified cells.

\section{Discussion}

We performed a series of experiments to explore the functional properties of broad thorny cells, a low-density ganglion cell type that has been morphologically identified in previous studies of various primates including human. The dendrites of broad thorny ganglion cells occupied the space between the ChAT bands in the IPL. Accordingly, broad thorny ganglion cells exhibited ON-OFF-center receptive fields. Center responses were strongly suppressed during simultaneous stimulation of the surround and showed slow kinetics relative to other cell types. Motion of an object in the receptive field center caused an augmented response when compared with stationary objects.

\section{Comparison with ganglion cells of other species}

Broad thorny ganglion cells have been considered to be primate homologs of LED ganglion cells in rabbit retina, based on the spiny appearance of the dendrites and their stratification in the IPL. LED ganglion cells are the smallest retinal ganglion cell type in rabbit, in terms of both their dendritic and receptive fields (Amthor et al., 1989; Devries and Baylor, 1997; Rockhill et al., 2002; van Wyk et al., 2006). However, the dendritic span of primate broad thorny cells clearly exceeds those of some other primate ganglion cells (Dacey et al., 2003) and their receptive fields are similarly large (this study). Also, the overall dendritic pattern of broad thorny cells caused by the recurving branchlets appears more regular, space-filling, and with less overlap than the dendrites of LED ganglion cells.

At first glance, the receptive field properties of broad thorny cells seem similar to those of LED ganglion cells (e.g., strong surround suppression of the ON-OFF-center response, fast and strong postsynaptic inhibition) but a closer inspection of the data reveals significant differences. A stationary spot presented to the receptive field center of LED ganglion cells causes a sustained spike response of $\geq 5$ s (Levick, 1967; van Wyk et al., 2006; Venkataramani et al., 2014). Spike responses of broad thorny cells, however, were very transient even for maintained stimuli. Broad thorny cells show vigorous responses to stimuli moving at fairly high velocities. In contrast, responses of LED ganglion cells apparently diminish at velocities $>\sim 2-3^{\circ}$ per second (Levick, 1967; Caldwell et al., 1978). Another striking distinction was revealed by measuring the area-response function of inhibitory synaptic currents in broad thorny cells. Postsynaptic inhibition increased with spot size and reached a maximum at spot sizes larger than the mean dendritic field size of the cells. However, postsynaptic inhibition in both response phases of LED ganglion cells is strongly suppressed by large stimuli (van Wyk et al., 2006; Venkataramani et al., 2014). These findings indicate differences in the response properties and synaptic circuitries of broad thorny ver- sus LED ganglion cells, differences that may go beyond mere adaptations that have occurred since the two species diverged. Thus, our findings argue against the hypothesis that the two cell types are homologous and certainly limit how much can be inferred from LED ganglion cells about broad thorny cell responses.

Another type of ON-OFF ganglion cell has been shown to costratify with LED ganglion cells in rabbit retina. This cell is termed the "transient ON-OFF RGC" (Sivyer et al., 2011). Dendritic fields of this ganglion cell type are relatively large with a dendritic substructure that is fairly similar to broad thorny cells. It should be noted, however, that the dendritic trees of transient ON-OFF RGCs show very closely spaced bistratification, which has not been reliably observed in broad thorny cells here or elsewhere (see above). The fact that the dendrites of broad thorny cells occupy only a single sublamina may prevent the detection of any bistratified pattern in the relatively thin IPL of peripheral macaque retina. On the other hand, the degree of dendritic bistratification in transient ON-OFF RGCs is very low, a feature that may not be of functional significance at the ON-OFF border in the IPL. Therefore, it could possibly be lost during evolution or "replaced" with a broad monostratification. More importantly, the transient ON-OFF RGC shows, as the name implies, transient light responses that are strongly suppressed from the receptive field's surround. There, just like in broad thorny cells, the surround suppression is caused by a combination of presynaptic suppression of excitatory inputs and strong postsynaptic inhibition, which persists during full-field stimulation. Thus, when compared with broad thorny ganglion cells, transient ON-OFF RGCs appear to be in some respects a better match than the LED ganglion cells. Other broadly stratifying primate ganglion cells (Yamada et al., 2005; their Fig. 8) may resemble the functional properties of LED ganglion cells more closely than broad thorny cells.

Morphologically similar ganglion cell types also exist in mouse retina (Sun et al., 2002; Völgyi et al., 2005; Helmstaedter et al., 2013; Sümbül et al., 2014). The gc44-52 ganglion cell appears to be a good candidate as a homolog of broad thorny ganglion cells (Helmstaedter et al., 2013). The cell stratifies in the very center between the ChAT bands while filling out the complete space between these bands. Their sparse dendritic twigs ascending farther toward the inner nuclear layer have also been occasionally observed here in broad thorny cells. Furthermore, dendrites of gc44-52 ganglion cells show the characteristic, recurving pattern and exhibit spines. According to Helmstaedter et al. (2013), this cell corresponds to the dimly labeled W3b ganglion cell in the TYW3 mouse line (Kim et al., 2010; Zhang et al., 2012). In contrast to the brightly labeled and well characterized W3a ganglion cell in this mouse line, very little is known so far about the W3b cell, so that a detailed comparison with primate broad thorny cells is not yet possible.

The response pattern of broad thorny cells suggests that they are able to reliably indicate whether an object slips away from its original position-largely independent of global motion, of the object speed or direction, or of the object being brighter or darker than the background. Some of these features are also found in cells of a nonmammalian model, the object motion-sensitive (OMS) ganglion cells of salamander retina (Baccus et al., 2008). The mouse W3 cell also showed OMS properties (Zhang et al., 2012) while the rabbit LED ganglion cells did not (Olveczky et al., 2003). The functional relationship between these cells, including primate broad thorny cells, remains uncertain. A proper comparison of OMS features between various cell types in different spe- 
cies needs to involve stimuli adjusted to the given cell's properties, such as its size, as well as to the properties of presynaptic subunits, and to the optical features of the eye, for instance.

A final conclusion in terms of homologous types in different species will require a more detailed investigation of the cellular and synaptic pathways, which drive the light responses of broad thorny ganglion cells. In addition, the catalog of ganglion cell types needs to be completed-in primate as well as in other species-before relationships between cell types can be unequivocally established.

\section{A role in visual guidance of pursuit movements?}

Functional properties of ON-OFF direction-selective cells and their circuitries, including their central projections, have been subject of intense investigation and are therefore fairly well understood (Borst and Euler, 2011). However, the functional roles of most other mammalian ON-OFF retinal ganglion cells remain elusive.

Broad thorny cells project to the koniocellular layers of lateral geniculate nucleus and to the superior colliculus (Rodieck and Watanabe, 1993; Dacey et al., 2003; Szmajda et al., 2008; Percival et al., 2011, 2013). These target areas are involved in the mediation of visually guided motor movements, including eye movements (Sparks, 2002) and in the direct projection from koniocellular layers of the LGN to the dorsal stream (Sincich et al., 2004), which is generally concerned with providing visual guidance of movements and the assessment of moving objects. Much work on the neural substrates underlying the visual guidance of movements has focused on direction-selective cells. These cells are important in the selection and initiation of ballistic movements with a particular direction and velocity. This is not the function of the broad thorny cells since they do not exhibit direction selectivity. However, a second role of our visual system is to correct and refine movements, keeping them on track as a target is pursued.

One example of where the properties of broad thorny cells could be useful is in triggering catch-up saccades during smoothpursuit eye movements (Lisberger, 2010). Catch-up saccades occur, for instance, when the predicted velocity or position of the tracked object during steady-state smooth pursuit changes abruptly (de Brouwer et al., 2002). During ongoing smooth pursuit, when the eyes are perfectly tracking an object, broad thorny cells are exposed to one of two possible scenes: either to a stationary image of the moving target fixed in location on the retina, or to the image of the background continuously drifting across the retina as a result of the eye movement. Our data suggest that neither of those scenes would elicit spiking activity in the cells. If the target slips away, however, the cells would respond with a robust, transient spike discharge, indicating the need of a movement to correct for the deviation of the target. For this particular task, information regarding the direction or position of the target is not necessarily required (Krauzlis et al., 2004).

It remains an enticing subject of future studies to further test hypotheses about the functional roles of broad thorny cells in guiding movement. For example, it would be possible to record their light responses while exposing the retina to images of natural scenes that are moved to simulate different stages of smoothpursuit or saccadic eye movements. Of course visually guided pursuit movements can involve other parts of our body, particularly our hand movements, the guidance of which is one of the most important functions of the dorsal visual stream. It will be important to keep these other possibilities in mind in designing and interpreting future experiments directed at understanding the function of these ganglion cells.

\section{Notes}

Supplemental material for this article is available at http://www.neitzvision. com/content/puller/pullerPCA.pdf: Principal Components Analysis of Broad Thorny Ganglion Cell Responses to a Binary Noise Stimulus. This material has not been peer reviewed.

\section{References}

Amthor FR, Takahashi ES, Oyster CW (1989) Morphologies of rabbit retinal ganglion cells with complex receptive fields. J Comp Neurol 280:97121. CrossRef Medline

Baccus SA, Olveczky BP, Manu M, Meister M (2008) A retinal circuit that computes object motion. J Neurosci 28:6807-6817. CrossRef Medline

Barlow HB, Hill RM (1963) Selective sensitivity to direction of movement in ganglion cells of the rabbit retina. Science 139:412-414. CrossRef Medline

Benardete EA, Kaplan E (1999) The dynamics of primate M retinal ganglion cells. Vis Neurosci 16:355-368. Medline

Berson DM (2008) Retinal ganglion cell types and their central projections. In: The senses: a comprehensive reference (Allan IB, Akimichi K, Gordon MS, Gerald W, Thomas DA, Richard HM, Peter D, Donata O, Stuart F, Gary KB, Bushnell MC, Jon HK, Gardner E, eds), pp 491-519. New York: Academic.

Borg-Graham LJ (2001) The computation of directional selectivity in the retina occurs presynaptic to the ganglion cell. Nat Neurosci 4:176-183. CrossRef Medline

Borst A, Euler T (2011) Seeing things in motion: models, circuits, and mechanisms. Neuron 71:974-994. CrossRef Medline

Caldwell JH, Daw NW, Wyatt HJ (1978) Effects of picrotoxin and strychnine on rabbit retinal ganglion cells: lateral interactions for cells with more complex receptive fields. J Physiol Lond 276:277-298. CrossRef Medline

Chichilnisky EJ (2001) A simple white noise analysis of neuronal light responses. Network 12:199-213. CrossRef Medline

Chichilnisky EJ, Kalmar RS (2002) Functional asymmetries in ON and OFF ganglion cells of primate retina. J Neurosci 22:2737-2747. Medline

Dacey DM (2004) Origins of perception: retinal ganglion cell diversity and the creation of parallel visual pathways. In: The cognitive neurosciences, third edition (Gazzaniga MS, ed), pp 281-301. Cambridge, MA: MIT.

Dacey DM, Peterson BB, Robinson FR, Gamlin PD (2003) Fireworks in the primate retina: in vitro photodynamics reveals diverse LGN-projecting ganglion cell types. Neuron 37:15-27. CrossRef Medline

Davenport CM, Detwiler PB, Dacey DM (2007) Functional polarity of dendrites and axons of primate A1 amacrine cells. Vis Neurosci 24:449-457. Medline

de Brouwer S, Yuksel D, Blohm G, Missal M, Lefèvre P (2002) What triggers catch-up saccades during visual tracking? J Neurophysiol 87:1646-1650. Medline

Devries SH, Baylor DA (1997) Mosaic arrangement of ganglion cell receptive fields in rabbit retina. J Neurophysiol 78:2048-2060. Medline

Ghosh KK, Goodchild AK, Sefton AE, Martin PR (1996) Morphology of retinal ganglion cells in a New World monkey, the marmoset Callithrix jacchus. J Comp Neurol 366:76-92. CrossRef Medline

Greschner M, Field GD, Li PH, Schiff ML, Gauthier JL, Ahn D, Sher A, Litke AM, Chichilnisky EJ (2014) A polyaxonal amacrine cell population in the primate retina. J Neurosci 34:3597-3606. CrossRef Medline

Helmstaedter M, Briggman KL, Turaga SC, Jain V, Seung HS, Denk W (2013) Connectomic reconstruction of the inner plexiform layer in the mouse retina. Nature 500:168-174. CrossRef Medline

Ivanova E, Hwang GS, Pan ZH, Troilo D (2010) Evaluation of AAVmediated expression of Chop2-GFP in the marmoset retina. Invest Ophthalmol Vis Sci 51:5288-5296. CrossRef Medline

Kim IJ, Zhang Y, Meister M, Sanes JR (2010) Laminar restriction of retinal ganglion cell dendrites and axons: subtype-specific developmental patterns revealed with transgenic markers. J Neurosci 30:1452-1462. CrossRef Medline

Krauzlis RJ, Liston D, Carello CD (2004) Target selection and the superior colliculus: goals, choices and hypotheses. Vision Res 44:1445-1451. CrossRef Medline

Levick WR (1967) Receptive fields and trigger features of ganglion cells in 
the visual streak of the rabbits retina. J Physiol 188:285-307. CrossRef Medline

Lisberger SG (2010) Visual guidance of smooth-pursuit eye movements: sensation, action, and what happens in between. Neuron 66:477-491. CrossRef Medline

Masland RH (2012) The neuronal organization of the retina. Neuron 76: 266-280. CrossRef Medline

Moritoh S, Komatsu Y, Yamamori T, Koizumi A (2013) Diversity of retinal ganglion cells identified by transient GFP transfection in organotypic tissue culture of adult marmoset monkey retina. PloS One 8:e54667. CrossRef Medline

Olveczky BP, Baccus SA, Meister M (2003) Segregation of object and background motion in the retina. Nature 423:401-408. CrossRef Medline

Percival KA, Martin PR, Grünert U (2011) Synaptic inputs to two types of koniocellular pathway ganglion cells in marmoset retina. J Comp Neurol 519:2135-2153. CrossRef Medline

Percival KA, Martin PR, Grünert U (2013) Organisation of koniocellularprojecting ganglion cells and diffuse bipolar cells in the primate fovea. Eur J Neurosci 37:1072-1089. CrossRef Medline

Perry VH, Cowey A (1985) The ganglion cell and cone distributions in the monkey's retina: implications for central magnification factors. Vision Res 25:1795-1810. CrossRef Medline

Peterson BB, Dacey DM (2000) Morphology of wide-field bistratified and diffuse human retinal ganglion cells. Vis Neurosci 17:567-578. CrossRef Medline

Rockhill RL, Daly FJ, MacNeil MA, Brown SP, Masland RH (2002) The diversity of ganglion cells in a mammalian retina. J Neurosci 22:38313843. Medline

Rodieck RW, Marshak DW (1992) Spatial density and distribution of choline acetyltransferase immunoreactive cells in human, macaque, and baboon retinas. J Comp Neurol 321:46-64. CrossRef Medline

Rodieck RW, Watanabe M (1993) Survey of the morphology of macaque retinal ganglion-cells that project to the pretectum, superior colliculus, and parvicellular laminae of the lateral geniculate-nucleus. J Comp Neurol 338:289-303. CrossRef Medline

Roska B, Molnar A, Werblin FS (2006) Parallel processing in retinal ganglion cells: how integration of space-time patterns of excitation and inhibition form the spiking output. J Neurophysiol 95:3810-3822. CrossRef Medline

Russell TL, Werblin FS (2010) Retinal synaptic pathways underlying the response of the rabbit local edge detector. J Neurophysiol 103:2757-2769. CrossRef Medline

Sincich LC, Park KF, Wohlgemuth MJ, Horton JC (2004) Bypassing V1: a direct geniculate input to area MT. Nat Neurosci 7:1123-1128. CrossRef Medline

Sivyer B, Venkataramani S, Taylor WR, Vaney DI (2011) A novel type of complex ganglion cell in rabbit retina. J Comp Neurol 519:3128-3138. CrossRef Medline

Sparks DL (2002) The brainstem control of saccadic eye movements. Nat Rev Neurosci 3:952-964. CrossRef Medline

Stafford DK, Dacey DM (1997) Physiology of the Al amacrine: a spiking, axon-bearing interneuron of the macaque monkey retina. Vis Neurosci 14:507-522. CrossRef Medline

Sümbül U, Song S, McCulloch K, Becker M, Lin B, Sanes JR, Masland RH, Seung HS (2014) A genetic and computational approach to structurally classify neuronal types. Nat Commun 5:3512. CrossRef Medline

Sun W, Li N, He S (2002) Large-scale morophological survey of rat retinal ganglion cells. Vis Neurosci 19:483-493. Medline

Szmajda BA, Grünert U, Martin PR (2008) Retinal ganglion cell inputs to the koniocellular pathway. J Comp Neurol 510:251-268. CrossRef Medline

Taylor WR, Vaney DI (2002) Diverse synaptic mechanisms generate direction selectivity in the rabbit retina. J Neurosci 22:7712-7720. Medline

van Wyk M, Taylor WR, Vaney DI (2006) Local edge detectors: a substrate for fine spatial vision at low temporal frequencies in rabbit retina. J Neurosci 26:13250-13263. CrossRef Medline

Vaney DI, Sivyer B, Taylor WR (2012) Direction selectivity in the retina: symmetry and asymmetry in structure and function. Nat Rev Neurosci 13:194-208. CrossRef Medline

Venkataramani S, Van Wyk M, Buldyrev I, Sivyer B, Vaney DI, Taylor WR (2014) Distinct roles for inhibition in spatial and temporal tuning of local edge detectors in the rabbit retina. PloS One 9:e88560. CrossRef Medline

Völgyi B, Abrams J, Paul DL, Bloomfield SA (2005) Morphology and tracer coupling pattern of alpha ganglion cells in the mouse retina. J Comp Neurol 492:66-77. CrossRef Medline

Wässle H (2004) Parallel processing in the mammalian retina. Nat Rev Neurosci 5:747-757. CrossRef Medline

Weng S, Sun W, He S (2005) Identification of ON-OFF direction-selective ganglion cells in the mouse retina. J Physiol 562:915-923. CrossRef Medline

Yamada ES, Dmitrieva N, Keyser KT, Lindstrom JM, Hersh LB, Marshak DW (2003) Synaptic connections of starburst amacrine cells and localization of acetylcholine receptors in primate retinas. J Comp Neurol 461:76-90. CrossRef Medline

Yamada ES, Bordt AS, Marshak DW (2005) Wide-field ganglion cells in macaque retinas. Vis Neurosci 22:383-393. Medline

Zeck GM, Xiao Q, Masland RH (2005) The spatial filtering properties of local edge detectors and brisk-sustained retinal ganglion cells. Eur J Neurosci 22:2016-2026. CrossRef Medline

Zhang Y, Kim IJ, Sanes JR, Meister M (2012) The most numerous ganglion cell type of the mouse retina is a selective feature detector. Proc Natl Acad Sci U S A 109:E2391-E2398. CrossRef Medline 